\title{
CONTESTING CYBERSPACE IN CHINA
}





\section{CONTESTING}

\section{CYBERSPACE}

\section{IN CHINA}

ONLINE EXPRESSION AND

AUTHORITARIAN RESILIENCE

\section{RONGBIN HAN}




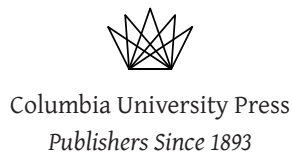

New York Chichester, West Sussex

cup.columbia.edu

Copyright (c) 2018 Columbia University Press

All rights reserved

Library of Congress Cataloging-in-Publication Data Names: Han, Rongbin, 1980- author.

Title: Contesting cyberspace in China : online expression and authoritarian resilience / Rongbin Han.

Description: New York : Columbia University Press, [2018] |

Includes bibliographical references and index.

Identifiers: LCCN 2017038716| ISBN 9780231184748 (cloth : alk. paper) |

ISBN 9780231184755 (pbk. : alk. paper) | ISBN 9780231545655 (ebook)

Subjects: LCSH: Internet-Government policy-China. | Internet-Political aspects-China. | Freedom of speech-China. | Censorship-China. |

Authoritarianism-China.

Classification: LCC HN740.Z9 I567434 2018 | DDC 302.23/10951-dc23

LC record available at https://lccn.loc.gov/2017038716

Columbia University Press books are printed on permanent and durable acid-free paper.

Printed in the United States of America

Cover design: Noah Arlow 
To my daughter, Audrey Zhiyan Han, and my wife, Yi Fu 
